\title{
Om å kunne si 'ånd' uten å skamrødme. En mulighet
}

\author{
Øivind Varkøy \\ Norges Musikkhøgskole
}

Lærerens grunnleggende verdisyn er av avgjørende betydning for hans eller hennes pedagogiske praksis. For en musikklærers vedkommende vil verdisynet inkludere et musikksyn. Med utgangspunkt i denne erkjennelsen drøftes i denne artikkelen forskjellen på kunst og underholdning, forholdet mellom kunsten, det hellige og mysteriøse, og musikk som et uttrykk for vilje til form. Refleksjonen knyttes til såpass ulike inspirasjonskilder som Dag Østerberg, Karl Ove Knausgård, Arthur Schopenhauer og Rudolf Steiner.

\section{Innledning}

Lærerens refleksjon omkring spørsmål om musikkens verdi, mening, vesen og/eller funksjon i individuelt og sosialt liv er av avgjørende betydning for den praksis som drives i klasserommene (se Reimer, 1970). Minst problematisk er det når slike sammenhenger er bevisste, reflekterte og åpne. Lærere som underviser i kunstfag, trenger derfor å utvikle estetisk kompetanse, det vil si en forståelse for musikk som kunstfag. Dale (1991) fremhever i denne sammenhengen kultur- og kunsthistorie samt filosofisk estetikk som vesentlige disipliner i utdanningen av lærere som skal undervise i kunstfag. (Dette naturligvis i tillegg til de sedvanlige disipliner av mer ferdighetsorientert karakter.) Læreren må utvikle bevissthet og refleksjon omkring musikkens mangespektrede eller flerdimensjonale meningsunivers (se Nielsen, 1994, s. 133ff.). I musikken finnes både akustiske, strukturelle, kroppslige (motoriske) emosjonelle og åndelige/eksistensielle meningslag - som muligheter, som potensial. Alle slike meningslag realiseres imidlertid først i møtet med det opplevende subjektet. Kunnskap om og refleksjon omkring dette er en forutsetning for at læreren kan åpne rom for alle de potensielle meningslagene i musikk, inklusive musikkens åndelige/eksistensielle lag, i sin undervisning. En slik grunnlagstenkning er nødvendig for å kunne drive profesjonell virksomhet som musikklærer, enten denne foregår i Steinerskoler

\footnotetext{
^Korrespondanse: Øivind Varkøy, epost: oivind.varkoy@nmh.no

(C) 2019 Øivind Varkøy. This is an Open Access article distributed under the terms of the Creative Commons Attribution 4.0 International License (https://creativecommons.org/licenses/by-nc/4.0/), allowing third parties to copy and redistribute the material in any medium or format and to remix, transform, and build upon the material for any purpose, even commercially, provided the original work is properly cited and states its license. 
eller offentlige skoler. Ett viktig element i denne sammenhengen er refleksjonen omkring forholdet mellom kunst og underholdning.

\section{Kunst og underholdning}

Sosiologen Dag Østerberg tilkjennegir kunstsynet sitt slik: «For å tone flagg: Ett er kunst, et annet underholdning» (2009, s. 446. Se også Østerberg \& Bjørnerem, 2017). Det å insistere på et skille mellom kunst og underholdning handler, slik jeg ser det, først og fremst om at det å forholde seg til noe som kunst er noe ganske annet enn å forholde seg til noe som underholdning. I motsetning til underholdningens politisk sløvende funksjon, fremhever Østerberg (2009) at kunsten «har å gjøre med livets alvor» (s. 446).

Det synes imidlertid å foregå en marginalisering av begrepet kunst i det musikkpedagogiske feltet. Et eksempel i så måte er utkastet til ny musikkfagplan for den norske grunnskolen. Her forekommer termen 'kunst' bare én gang i teksten: «Musikk og kunst kan hjelpe oss med å bryte ned forestillingen om at kultur og natur er koblet fra hverandre og bygge bro mellom mennesket og naturen» (Udir., 2018). (Ellers forekommer begrepet kunstnerisk' tre ganger i dokumentet.) Det er neppe urimelig å se fraværet av kunstbegrepet i lys av den omfattende musikkvitenskapelige og musikkpedagogiske kritikken av den vestlige klassiske musikktradisjonen og dens påståtte ensidige fokus på musikk som kunstverk og objekt. De siste tiårene har man gjerne drøftet musikk som noe vi gjør sammen, altså som prosess og verb, mer enn et produkt, objekt og kunstverk (se f.eks. Elliott, 1995 og Small, 1998).

En slik tolkning styrkes av at utkast til fagplan ellers preges av alternative diskursersom kommer til uttrykk ved at musikk for eksempel beskrives som «livslang estetisk og sosial kulturaktivitet» og "sosial, kulturell og estetisk meningsbærende og meningsskapende praksis» (Udir., 2018). Isolert sett er dette uproblematiske utsagn. Det er når de leses i lys av fraværet av kunstbegrepet at de ideologiske perspektivene blir problematiske. Jeg holder imidlertid fast ved at musikk er en kunstform, og at man også i det pedagogiske må kunne forholde seg til det. Dette synspunktet står på ingen måte i motsetning til at musikk er sosial og kulturell praksis, men er nødvendig for å kunne forholde seg til forskjellen mellom kunst og underholdning, hvor kunst i motsetning til underholdning da handler om livets alvor. I et slikt perspektiv blir det ett sentralt poeng at mens underholdningen har avkobling og rekreasjon som siktemål, vil kunsten handle om tilkobling og utfordring, ikke minst i møte med våre eksistensielle grunnvilkår: sårbarhet og dødelighet, ensomhet og relasjoners skjørhet, angst og glede, og stadig søken etter mening. Mens underholdningen tilbyr oss høyst nødvendige, men dog forglemmelige opplevelser, er kunstens like nødvendige bidrag muliggjøringen av dypere erfaringer, erfaringer som kan få betydning for videre livsløp og -valg.

Refleksjonen omkring forholdet mellom kunst og underholdning er altså ett viktig element i lærerens bevisstgjøring av sitt eget musikksyn. Om læreren skal kunne åpne 


\title{
Øivind Varkøy
}

rom for musikkens åndelige eller eksistensielle lag, altså livets alvor, er det et annet sentralt element i refleksjonen som han eller hun også bør kunne forholde seg til: nemlig relasjonen mellom kunsten og det vi kan våge å omtale som 'det hellige' og 'musikkens mysteriøse karakter'.

\section{Det hellige og mysteriøse}

I essayet "Hvordan jeg ikke oppdaget Amerika» (2018) gjør Karl Ove Knausgård seg følgende refleksjon:

\begin{abstract}
Kunsthistorien er ingenting annet enn historien om menneskenes representasjon av det hellige [...] Kunsten viser oss noe i verden vi vanligvis ikke ser, men som vi kjenner, og som kunsten løfter oss opp til, i sine verdensintensiverende fortetninger ... At kunsten de siste hundre årene ikke har søkt det hellige, forandrer ikke på det, det forteller bare at det hellige ikke lenger er en kategori som blir regnet med ... (s. 100-111).
\end{abstract}

Knausgårds påstand om at kunsten de siste hundre årene ikke har søkt det hellige, er imidlertid høyst diskutabel. Det er lite som tyder på at det metafysiske stadium er forlatt i dagens kunstfelt. For det første forholder en lang rekke av samtidens kunstnere seg eksplisitt til "det hellige», ikke minst musikere knyttet til bestemte religiøse tradisjoner, for eksempel Leonard Cohen, Arvo Pärt og vår egen Lasse Thoresen, som hhv. jøde, ortodoks kristen og bahai (se f.eks. Thoresen, 2004; Varkøy, 2017, 2004).

For det andre finnes det mange spor av kristen symbolikk og tematikk også blant norske forfattere, bildekunstnere og komponister - med ulike forhold til klart definerte religiøse tradisjoner. For uten Knausgård selv, for eksempel Dag Solstad, Gunvor Hofmo og Stig Sæterbakken, Håkon Bleken, Arne Nordheim og Anne Grete Preus (se f.eks. Hovdelien \& Kristiansen, 2007; Oftestad, 2018).

For det tredje er det ikke vanskelig å oppspore norske musikkforskere og komponister som er opptatt av relasjoner mellom musikken, det hellige og mysteriøse. I arbeidet med antologien Musikk og mysterium (2004) utviklet Erling E. Guldbrandsen (professor i musikkvitenskap ved Universitetet i Oslo) og jeg en slags «lakmustest» når det gjaldt hvem som kunne være mulige bidragsytere $\mathrm{i}$ en slik bok. Vedkommende måtte kunne si 'ånd' - uten å skamrødme. På ett nivå var dette humoristisk ment fra vår side. På et annet nivå alvor. Vi ønsket å utfordre dominerende diskurser innenfor det etablerte musikkfaglige feltet, hvor de hevdvunne talemåtene sjelden klarer eller ønsker å si noe om den personlige musikalske erfaringen, når musikken griper tak og skaker oss, styrter oss mot ukjente svelg eller mumler stillferdig om eksistensen. Vi fant en rekke mennesker innenfor musikkfeltet, som gjerne imøtekom dette ønsket. På tross av forskjeller seg imellom når det gjaldt livs- og verdensanskuelser, hadde de alle et forhold til og personlige erfaringer med musikken og det flere av dem valgte å omtale som det hellige og mysteriøse. De våget også å skrive om det og søkte slik å finne igjen det metafysiske, å lete opp det religiøse og gjenreise den åndelige dimensjonen 
i musikkerfaringen (se Dahl, 2018; Varkøy, 2018; Skagen, 2018 for en drøfting av slik tematikk på generell basis).

Umiddelbart synes termene «det hellige» og «det mysteriøse» å rokke ved musikkforståelsen i vår avfortryllede verden (se Weber, 1995), dominert av den tekniske rasjonalitetens jernbur - hvor det ikke er plass til det åndelige, til mysteriet (Taylor, 2007, s. 356), og hvor kunst, så vel som religion, er forvist til feltet for irrasjonell tro eller ukontrollerte følelser (se von Wright, 1994, s. 18). Tidens hegemoniske musikkestetiske, -psykologiske, -sosiologiske, -kulturteoretiske, -pedagogiske og -terapeutiske talemåter utfordres, altså, idet vi våger å nærme oss det som skjer når musikken fremstår som et skakende møte med «Noko anna - Som heile tida er der - Annleis - og som det same», som Jon Fosse sier i et dikt (Fosse 2001, s. 204).

Om vi tenker at vi i det kunstpedagogiske bør kunne forholde oss til termer og fenomener som det hellige og det mysteriøse, kan én mulighet være en bevegelse $\mathrm{i}$ retning av en re-romantisering av tenkningen omkring den musikalske erfaringen, en vending i retning av ærefrykt og undring (se Han, 2018a). I en slik sammenheng trenger vi, slik jeg ser det, å forholde oss til den musikalske erfaringen som noe som handler mer om opplevelse av vilje til form enn om følelser.

Ovenfor har forholdet mellom kunst og underholdning, og relasjonen mellom kunsten og det hellige og mysteriøse, blitt løftet frem som to sentrale elementer i en estetisk refleksjon som skal åpne for åndelig og eksistensiell erfaring av musikk som kunst - som livets alvor. Et tredje element, nært forbundet med de to foregående, er nettopp forestillingen om musikk som vilje til form.

\section{Vilje til form}

En slik tenkemåte kommer svært tydelig til uttrykk i Arthur Schopenhauers musikktenkning, som av enkelte betraktes som et toppunkt i romantisk musikktenkning. Hva kjennetegner en romantisk posisjon? I helt korte trekk: På 1800-tallet utvikles en musikkforståelse i retning av nyplatonisme og mystikk; musikken strekker seg ut over språket, den sier noe om det språket ikke kan nærme seg. Spesielt instrumentalmusikk anses å uttrykke noe som er uoversettelig i forhold til ethvert verbalspråk. Musikken åpner opp for 'det uutsigelige' (jf. bl.a. Wackenroeder \& Tieck i Kjerschow, 2014, s. 150ff.). Schopenhauers kunst- og især musikktenkning er et lyspunkt i en ellers dyster tankeverden, hvor kunstneren gjennom den rene kunstneriske anskuelse av livets mangfold blir den som kan befri oss fra livets lidelser, trykk og kval. I Schopenhauers tenkning er musikken et direkte uttrykk forViljen: den indre natur i alle fenomener. Musikken gir slik innsikt i noe fornuften ikke kan gripe: nemlig formkreftene (Kjerschow, 2000). Her finnes et slektskap med de gamle grekernes musikktenkning, hvor det er intet mindre enn den kosmiske orden, tilværelsens bakenforliggende harmoniske strukturer, som kommer til uttrykk i den gode musikken (se Sundberg, 1980, 2000; Varkøy, 2015). En slik tenkning gjenspeiles også hos Augustin (se Augustinus, 2017; Pickstock, 1999). 


\section{Øivind Varkøy}

En særegen representant for det vi kanskje kan kalle et romantisk-kosmisk musikksyn, er Rudolf Steiner. Steiner hevder at vi i den drømmeløse søvn vandrer gjennom det musikalske tonehavet, hvor 'den store stillheten' klinger. De store mesterne formidler så intuitivt den mentale verden vi erfarer i drømmeløs søvn:

Fra dens (sjelens) opprinnelige hjemstavn, fra den åndelige verden, toner musikkens klanger til oss og taler trøstende og oppløftende til oss i bølgende melodier og harmonier (Steiner, 1989, s. 31, sitatet er oversatt av forfatteren).

Dette ligger til grunn for vår dragning mot 'den store musikken'. Når vi hører stor musikk, føler vi oss vel til mote fordi tonene er i overensstemmelse med det kosmos, de formkrefter, vi har opplevd i den åndelige verdenen som sjelen vandrer gjennom i den drømmeløse søvn; vi aner en skygge av vår åndelige opprinnelse (se Varkøy, 2015, kapittel 6). Som Ingmar Bergman (IB) formulerer dette i en samtale med datteren Linn Ullman (LU):

IB: Gud er der musikken er. Jeg tror de store komponistene forteller om sine opplevelser av Gud. Dette er ikke tøv. Bach er for meg en uforanderlig faktor.

LU: Men før tvilte du?

IB: Ikke på Bach.

(Ullmann, 2015, s. 145).

Nå vil muligens mange i dag vurdere slike talemåter, romantisk musikktenkning generelt og Steiners tenkning spesielt, som både relativt spekulative og av en lang rekke årsaker absolutt utdaterte. Jeg skal ikke gå inn i en slik diskusjon her. Jeg skal nøye meg med å påpeke det faktum at en slik vurdering i så fall også vil kunne ramme tradisjonell kristen musikktenkning og mystikk (se Varkøy, 2004). Et eksempel i så måte er hvordan man ut ifra en såkalt 'naturlig teologisk' tankegang vil mene at vi kan finne spor av Skaperen i naturen, i skaperverkets storhet og skjønnhet. Som Augustin formulerer det (en god stund for 'naturlig teologi' var et begrep): «[D] et skjønne som fra kunstnerens sjel går over til hans hender, det stammer fra den skjønnhet som er opphøyd over sjelene». Det handler om spor av det usynlige i det synlige, av det uhørte i det hørte (se f.eks. Kristiansen, 2014). Mer inspirert av naturlig teologi enn av Schopenhauer (strengt filosofisk sett), kan man da kanskje tenke at dette 'usynlige', 'uhørte' og 'stumme' kan være viljen til form?

Vel - da har vi utvilsomt havnet i et tankemessig landskap som skiller seg radikalt fra det meste av musikktenkning i vår tid, preget som denne er av de nevnte psykologiske, terapeutiske, pedagogiske, sosiologiske og kulturteoretiske talemåter. Dette har da også vært denne tekstens hensikt: å peke på muligheten av noe annet, i retning av åndserfaringer som ikke uten videre kan beskrives og forklares ved de nevnte talemåtene alene. Denne muligheten av noe annet, slik dette på ulikt vis kommer til uttrykk hos Schopenhauer, Steiner og i kristen tenkning, kan umiddelbart kanskje virke fremmed og sært. Men - om vi beveger oss fra teologien og over til filosofien igjen, viser det seg imidlertid at det ikke mer merkelig enn at også den amerikanske 
filosofen Martha Nussbaum (2016) i en diskusjon av forholdet mellom litteratur og etisk tenkning fremhever hvordan litteraturens evne til å vekke følelser også skjer gjennom verkets struktur og form. I denne sammenhengen viser Nussbaum til Platons og Aristoteles' "subtile redegjørelse for hvordan de litterære formene i seg selv formidler et budskap, et syn på hva som er verdt å ta på alvor, og hvordan verden er» (s. 46).

Ved å reflektere over forholdet mellom kunst og underholdning, kunst som det som handler om livets alvor, kunsten og det hellige og musikkens mysteriøse karakter forstått som vilje til form - inviteres vi inn i en musikk- og kunstforståelse som innbyr til ærefrykt og undring, varighet og kontemplasjon. I stedet for at vi underlegger oss en følelsesdominert forbrukermentalitet, hvor hedonistisk nytelse og forbruk forventes å gjenfortrylle våre prosaiske liv, åpnes et rom for en motstandens estetikk - et alternativ til konsumkulturens glatthet (se Han, 2017, 2018b; Bleken, 2012): et rom i klasserommet, hvor lærere og elever i samspill og samtale kan forholde seg til og si 'ånd' - uten å skamrødme.

\section{Forfatteromtale}

Øivind Varkøy er utdannet musikkviter og musikkpedagog, med doktorgrad i musikkvitenskap. Han er i dag professor i musikkpedagogikk og leder for ph.d.programmet ved Norges musikkhøgskole og professor II i musikk ved OsloMet Storbyuniversitetet. Fra 2008 til 2011 var Varkøy professor i musikkvitenskap ved Örebro universitet. Han har publisert en rekke bøker og artikler innenfor emnet musikkpedagogisk filosofi, både på norsk, svensk, engelsk og tysk. Hans seneste bok på norsk er Musikk - dannelse og eksistens (Cappelen Damm Akademisk, 2017). Varkøy er også komponist og har skrevet musikk for blant annet Morten Harket, Kåre Conradi og Solveig Slettahjell. Varkøys seneste musikalske utgivelse er CD-en Poetisk tale (Solveig Slettahjell. Kirkelig Kulturverksted, 2016).

\section{Referanser}

Augustin (1974). Bekjennelser. Oslo: Gyldendal.

Augustinus (2017). De Musica. Berlin: De Gruyter.

Bleken, H. (2012). Motstandens estetikk. I Ø. Varkøy (red.), Om nytte og unytte, (s. 159-162). Oslo: Abstrakt forlag.

Dahl, H. F. (2018). Åndelig atterreising no! Dag og Tid, 11. mai, 2018.

Dale, E. L. (1991). Kunnskapens tre og kunstens skjønnhet. Oslo: Gyldendal.

Elliott, D. (1995). Music Matters. Oxford: Oxford University Press.

Fosse, J. (2001). Dikt 1986-2000. Oslo: Samlaget.

Guldbrandsen, E. E., \& Varkøy, Ø. (red.). (2004). Musikk og mysterium. Fjorten essay om grensesprengende musikalsk erfaring. Oslo: Cappelen Akademisk Forlag.

Han, B.-C. (2018a). Lob der Erde. Berlin: Ullstein Buchverlage GmbH.

Han, B.-C. (2018b). Saving Beauty. Cambridge: Polity Press.

Han, B.-C. (2017). Psychopolitics. Neoliberalism and new technology of power. London and New York: Verso. 


\section{Øivind Varkøy}

Hovdelien, O., \& Kristiansen, S. J. (red.). (2007). Fra Dante til Umberto Eco. Atten tekster om teologi og litteratur. Oslo: Unipub.

Kjerschow, P. C. (2014). Musikken - fra grepethet til begrep. Musikkfilosofiske tekster fra Platon til Cage. Oslo: Vidarforlaget.

Kjerschow, P. C. (2000). Verden og kunsten i Schopenhauers filosofi. I Før språket. Musikkfilosofiske essays, ss. 45-64. Oslo: Vidarforlaget.

Knausgård, K. O. (2018). Hvordan jeg ikke oppdaget Amerika. I I kyklopenes land. Tekster 2009-2018. Oslo: Forlaget Oktober.

Kristiansen, S. J. (2014). Avdekning og tilsløring. Dionysios Areopagitens symboltenkning og fean-Luc Marions ettermoderne kunstfilosofi. (Ph.d.-avhandling i kunsthistorie). Bergen: Universitetet i Bergen.

Nielsen, F. V. (1994). Almen musikdidaktik. København: Eijlers forlag.

Nussbaum, M. C. (2016). Litteraturens etikk. Oslo: Pax forlag.

Oftestad, T. (2018). Mellom juleidyll og inferno. Kristen motivbruk i Stig Sæterbakkens roman Gjennom natten. I S. J. Kristiansen \& P. Solberg (red.), SEGL. Katolsk årsskrift for religion og samfunn, (s. 253-260). Oslo: St. Olav forlag.

Pickstock, C. (1999). Music, Soul, City and Cosmos after Augustin. I J. Milbank, C. Pickstock \& G. Ward (red.), Radical Ortodoxy, (s. 243-277). London and New York: Routledge.

Reimer, B. (1970). A Philosophy of Music Education. New Jersey: Prentice Hall.

Skagen, K. (2018). Norge, vårt Norge. Oslo: Dreyer forlag.

Small, C. (1998). Musicking. The Meanings of Performing and Listening. Middletown: Wesleyan University Press.

Steiner, R. (1989). Det musikalskes vesen. Odense: Jupiter.

Sundberg, O. K. (1980). Pythagoras og de tonende tall. Oslo: Solum forlag.

Sundberg, O. K. (2000). Musikktenkningens historie. Antikken. Oslo: Solum forlag.

Taylor, C. (2007). A Secular Age. Cambridge, MA, and London, England: The Belknap Press of Harvard University Press.

Thoresen, L. (2004). Inspirasjon og skapende prosesser. I E. E. Guldbrandsen \& Ø. Varkøy (red.). (2004), Musikk og mysterium. Fjorten essay om grensesprengende musikalsk erfaring, (s. 111-125). Oslo: Cappelen Akademisk Forlag.

Udir (18. oktober, 2018). Hentet fra https://hoering.udir.no/Hoering/v2/276?notatId=549.

Ullmann, L. (2015). De urolige. Oslo: Forlaget Oktober.

Varkøy, Ø. (2004). En stille susen. Tre musikalske erfaringer i en kristen kontekst. I E. E. Guldbrandsen \& Ø. Varkøy (red.). (2004), Musikk og mysterium. Fjorten essay om grensesprengende musikalsk erfaring, (s. 192-208). Oslo: Cappelen Akademisk Forlag.

Varkøy, Ø. (2015). Hvorfor musikk? En musikkpedagogisk idéhistorie, Oslo: Gyldendal Akademisk.

Varkøy, Ø. (2017). Du vil ha det mørkere. Leonard Cohen: Populærkulturens mystiker. I S. J. Kristiansen \& P. Solberg (red.), SEGL. Katolsk årsskrift for religion og samfunn, (s. 31-38). Oslo: St. Olav forlag.

Varkøy, Ø. (2018). Mystikk og fornuft. En historie om åndskamp i Norge. I S. J. Kristiansen \& P. Solberg (red.), SEGL. Katolsk årsskrift for religion og samfunn, (s. 342-346). Oslo: St. Olav forlag.

von Wright, G. H. (1994). Myten om fremskrittet. Oslo: Cappelen.

Weber, M. (1995). Den protestantiske etikk og kapitalismens ånd. Oslo: Pax forlag.

Østerberg, D. (2009). Musikklandskapets forvandling. I Nytt Norsk Tidsskrift, Nr. 3-4, 26. prgang, $445-454$.

Østerberg, D., \& Bjørnerem, R. T. (2017). Musikkfeltet. Innføring i musikksosiologi. Oslo: Cappelen Damm Akademisk. 